\title{
Do what I say, not what I do. Are we linking research and decision-making about invasive species in Patagonia?
}

\author{
Christopher B. Anderson ${ }^{1,2, 凶}$ \& Alejandro E. J. Valenzuela ${ }^{1,3}$ \\ 1. Instituto de Ciencias Polares, Ambiente E Recursos Naturales, Universidad Nacional de Tierra del Fuego, Ushuaia. \\ 2. Centro Austral de Investigaciones Científicas, Consejo Nacional de Investigaciones Científicas y Técnicas, Ushuaia. 3. \\ Coordinación de Patagonia Austral, Administración de Parques Nacionales, Ushuaia
}

\begin{abstract}
Aвstract. Invasion biology is well-positioned epistemologically, theoretically and practically to address the challenge of being both scientifically and socially relevant. Yet, how well are we achieving these two dimensions of academic inquiry and impact? We explored this issue by a) surveying Argentine invasion biology practitioners (students, scientists and managers) to determine the types of collaborations they report and their stated preferences regarding research thematic priorities (autecology, impacts, management, patterns/distribution, presence/absence, processes/mechanisms, policy, social), and b) reviewing the invasion biology literature in Argentine Patagonia to establish research productivity, the publications' taxonomic, methodological (review, inventory, sampling, experimental, modeling) and thematic foci, and the journals, languages and accessibility of publications. Finally, we compared the stated preferences ("expected frequency") with the publication literature review ("observed frequency"). We found all three respondent groups had a similar research prioritization. Management, policy and impact studies were considered the most important themes. Research on invasion biology has increased substantially but only $20 \%$ of respondents reported joint publications between managers and scientists. Also, we found biases towards impact research and sampling methods. Compared to the total invasive species assemblage, only a few species and taxonomic groups are well studied in Patagonia (e.g., salmonids, deer and Castor canadensis and Undaria pinnatifida). A significant difference was discovered between what invasive species researchers say is important and what they actually study. Impact research was overrepresented in the literature, while social, policy and management studies were under-produced, compared to stated preferences. Various scenarios could explain this discrepancy. A time lag may exist, whereby the reviewed publications reflect an antiquated mentality focused on the invasive species' autecology and impacts. A more troubling possibility is that Patagonia lacks scientific evaluation and funding structures that allow researchers to fulfill their own (and society's) priorities and to conduct applied and socially relevant endeavors, rather than purely theoretical studies.
\end{abstract}

[Keywords: epistemology, exotic species, review, science-society, social dimensions]

RESUMEN. Haz lo que yo digo, no lo que yo hago. ¿Vinculamos la investigación sobre invasiones biológicas en la Patagonia con la toma de decisiones?: La biología de invasiones está bien posicionada al nivel epistemológico, teórico y práctico para ser relevante científicamente y socialmente. No obstante, ¿cumplimos con estas dos dimensiones del estudio e impacto académico? Exploramos este tema mediante a) encuestas a profesionales relacionados con la biología de invasiones de Argentina (estudiantes, científicos y gestores) para determinar los tipos de colaboración que mantienen entre ellos y sus preferencias respecto de prioridades temáticas de investigación (autoecología, impactos, manejo, patrones/distribución, presencia/ausencia, procesos/mecanismos, políticas públicas, social), y b) revisión de la literatura sobre biología de invasiones en la Patagonia argentina para cuantificar la investigación, describir el enfoque taxonómico, metodológico (revisión, inventario, muestreo, experimento, modelamiento), la temática de las publicaciones y las revistas, idioma y accesibilidad de las publicaciones. Finalmente, comparamos la preferencia declarada ("frecuencia esperada") con la revisión de la literatura ("frecuencia observada"). Los tres grupos priorizan los temas de investigación de forma similar. Los estudios sobre manejo, políticas públicas e impactos de las especies invasoras fueron los más frecuentes. La investigación se ha incrementado sustancialmente, pero sólo $20 \%$ de los encuestados tuvieron publicaciones en conjunto entre científicos y gestores. Encontramos sesgos hacia la investigación de impactos y métodos de muestreo. Sólo unas pocas especies y grupos taxonómicos fueron bien estudiados en la Patagonia (e.g., salmónidos, ciervos, Castor canadensis y Undaria pinnatifida). Detectamos discrepancias entre lo que los investigadores señalan como prioritario y lo que realmente estudian. Mientras que las investigaciones sobre impactos aparecieron sobre-representadas en la literatura con respecto a las prioridades declaradas, los estudios sobre aspectos sociales, políticas y manejo estuvieron sub-representados. Esta discrepancia podría explicarse, por un lado, porque las publicaciones revisadas podrían reflejar una mentalidad anticuada enfocada en la autoecología e impactos de las especies invasoras. Pero por otro lado, una posibilidad más preocupante podría ser que la Patagonia carezca de estructuras e incentivos de evaluación y financiamiento que permitan a los investigadores el desarrollo de actividades aplicadas y socialmente relevantes, cumpliendo así con sus propias prioridades (y las de la sociedad), en lugar de estudios exclusivamente teóricos.

[Palabras clave: epistemología, especies exóticas, revisión, ciencia-sociedad, dimensiones sociales] 


\section{INTRODUCTION}

By the late 1980s, leading ecologists around the world began forcefully calling for the linkage of basic research with applied endeavors, such as education and decisionmaking (Lubchenco et al. 1991). In Argentina, as well, there has been an academic debate regarding the social role of ecologists and the field of ecology (Donadio 2009; Gurvich et al. 2009; Núñez et al. 2009). Indeed, the (re)validation of problem-driven ecological science has led to new research approaches, such as ecosystem services, that explicitly link the environment and human well-being (MEA 2005), and concomitantly major science funding agencies, including the U.S. National Science Foundation and the European Commission, now have incorporated societal impacts as an explicit part of the formal peerreview evaluation process that traditionally only included intellectual merit (Holbrook \& Frodeman 2011).

Within Ecology, the legitimization of applied research questions has been part of a broader disciplinary recognition of the need to integrate the study of humans and nature (Pickett \& Ostfeld 1995). As such, ecologists today are striving to conceptualize combined socio-ecological systems and to operationalize mechanistic and predictive models that not only allow us to study them (Collins et al. 2011), but also apply our knowledge to realworld scenarios (Carpenter et al. 2009). In this context, invasion biology stands out as a subdiscipline of ecology that from its inception has ostensibly been interested in addressing research questions that would be relevant for the management of harmful species and the conservation of impacted native biotic communities and ecosystems (Elton 1958). Yet, prevailing paradigms (sensu Kuhn 1962) within ecology at the time Charles Elton coined the "invasion" metaphor placed greater emphasis on theoretical research, relegating more practical concerns to the purview of applied disciplines like wildlife management, forestry and agronomy (MacIntosh 1986). By the 1980s, however, the shift towards more socially relevant ecological research meant that invasion biology was epistemologically and practically well-positioned to experience a period of growth.

The establishment of the Scientific Committee on Problems in the Environment (SCOPE) working group on invasion biology in 1984 catalyzed a subsequent academic interest in these questions on both theoretical and applied grounds (Huenneke et al. 1988), specifically enumerating the following questions for a research agenda within the fledgling sub-discipline: 1) What are the characteristics of a successful invader, 2) What are the characteristics of an invadible ecosystem, 3) How do we predict the impact and effects of an introduction, and 4) What are the implications for management and conservation? The ensuing establishment of two scientific journals in the late 1990s (Diversity $\mathcal{E}$ Distributions and Biological Invasions), as well as the publication of various books (Williams 1996) and text books (Lockwood et al. 2007) ushered in an era not only of high productivity and growth, but of academic and institutional consolidated and legitimization (Davis 2006).

Today, invasion biology has proven itself to be a highly prolific line of scientific inquiry, displaying exponential increase in the number of publications produced in Latin America since 2000 (Pauchard et al. 2011). Pysek et al. (2006) further demonstrated that not only is the amount of research increasing, but indeed the citation rate of the top papers in invasion biology exceeded that of other major ecology sub-disciplines like population biology and climate change research. Nonetheless, as a research paradigm to constructively solve scientific problems, invasion biology has been criticized as ineffective at answering the questions and achieving the conservation outcomes it laid out for itself in the 1980s (Davis et al. 2011). The debate surrounding its relative merits and achievements has become sometimes acrimonious and even personal (see June and July 2011 entries in Alien's Listserv, managed by the Invasive Species Specialist Group; www.issg.org). However, Simberloff et al. (2011) and 141 co-signatories rebutted these charges academically by arguing that 1) most invasion biologists do not confound all exotic species with harmful invasives, 2) both scientists and managers also recognize the potential benefits of introduced species, and 3) control programs for harmful invasive species are not only necessary, but increasingly effective.

Yet, the invitation to pause and reflect on the research we ecologists and invasion biologists are conducting should be an iterative exercise, and also we must incorporate multiple geographic and institutional scenarios into 
the analysis. We put forward, therefore, that it is useful to "examine ourselves in the mirror" to see if the reflection is true to what we think we look like. Therefore, this paper addresses how invasion biology practitioners, including students, researchers and managers, approach the study of invasive species in Argentine Patagonia. Argentina is one of the most scientifically productive Latin American countries in invasion biology, considering the number of peer-reviewed publications (Pauchard et al. 2011; Speziale et al. 2012), but what kind of studies are we conducting?

We analyzed two aspects of the academic dimensions of invasion biology in Patagonia: 1) the stated research priorities of invasion biology practitioners and 2) the questions, taxa and methods being employed in invasion biology research. Given the drive to promote high quality scientific research (e.g., the prioritization of ISI and English language international journals, see Monjeau et al. 2013), we hypothesized that the incentive structure of academia would bias results towards basic theoretical research rather than applied studies, regardless of stated priorities and values expressed by invasion biology practitioners or the founding principles of the sub-discipline itself.

\section{Materials \& Methods}

To answer the questions laid out above about the research priorities and academic products of invasion biology in Patagonia, we undertook a twofaceted approach: a) a survey of invasion biology practitioners to determine their stated research priorities and b) a bibliographic literature review to describe their actual academic research output. We focused our analysis on the Argentine portion of Patagonia, but also include comparisons to the rest of the country and other parts of the region (e.g., Chile: Quiroz et al. 2009; Latin America: Pauchard et al. 2011; Speziale et al. 2012).

\section{Determining how we think}

We sought to characterize invasion biology practitioners, including students, scientists and managers, and their "mentalities" by applying a quantitative and qualitative survey instrument that collected basic demographic data, links between research and application and the respondent's prioritization of a range of research topics (see survey in Appendix S1 in Supplementary Information). Paper surveys were distributed and collected among participants in the Invasions in Patagonia Symposium, organized during the $25^{\text {th }}$ Meeting of the Argentine Ecological Association.
Subsequently, the same survey was distributed online to the Especies Exóticas de Argentina Facebook Group. For each respondent, we asked career status (undergraduate student, graduate student, scientist, manager or other) and the types of interactions they engage in between scientists and managers (joint proposal development, joint publications, workshops, advisory services, participation in policy development). Each, then, was asked to rank a series of nine affirmations regarding research topical themes to prioritize them from most to least important, using the Q methodology (McKeown \& Thomas 1988). These specific statements (see Appendix S1) were classified as being related to the following broader approaches to invasion biology, which were modified from Pauchard et al. (2004) by adding social, political and applied areas. Topics included the following: 1. ecology of the invasive species (Autecology1), 2. ecology of the native ecosystem (Autecology 2), 3. invasive species / community patterns \& distributions (Patterns), 4. invasive species inventories of presence $\&$ absence (Presence), 5. social dimensions of invasive species (Social), 6. invasive species impacts (Impacts), 7. applied management techniques for invasive species control or mitigation (Management), 8. processes \& mechanisms of invasion (Processes), and 9. policy-making for invasive species control or mitigation (Policy).

To analyze these data, we report percentage for each professional category and type of collaborative activity. We then converted the ranking exercise to a numerical scale, where each affirmation was considered: Very important $=2$, Important $=1$, Neutral $=0$, Less important $=-1$ and Unimportant $=-$ 2. Then, a two-way ANOVA was applied to consider if research topic prioritization was affected by professional group (students, researchers, managers) and affirmation research theme (1-9). Significant differences were then determined at $P<0.05$ with a Tukey HSD "post hoc" test. ANOVA tests were conducted with JMP 10.0 (SAS).

\section{Determining what we do}

To evaluate the scientific research productivity and kinds of investigation being conducted by invasion biology practitioners, we carried out a bibliographic review of the extant literature in the Web of Knowledge database from 1989-2011. This database included articles that were ISI Web of Science (WOS), Biosis and Zoological Records (Zoorec). We used the following combination of key words: invasi* + Argentina, or exotic + Argentina, or alien + Argentina. We then filtered the results to include journals from the following categories: Environmental Science \& Ecology, Marine \& Freshwater Biology, Agriculture, Entomology, Forestry, Fisheries, Oceanology and Veterinary Science. Subsequently, we excluded conference proceedings and were left with only articles and reviews. 
Each article was evaluated individually to determine whether the research had taken place in Patagonia and whether the article or its abstract was written in Spanish. The studied taxon (or taxa) was categorized as plant, animal or both, and the phase of invasion evaluated by the study was classified as either: introduction, establishment or invasion. Since we were also interested in the methods being used to obtain data, we classified each paper as being based on a review, field sampling, experiment or model. Also, regarding the types of questions being asked, we assessed the objective of each study as per the Pauchard et al. (2004) rubric: autecology, impacts, presence/absence (or inventories), patterns (or distributions), processes (or mechanisms), management or other. To compare the overall trend in academic invasion biology publications with that of the broader discipline of ecology, we conducted a search as well for "ecology" (topic) + "Argentina" (topic) or "Argentina" (address) with the same filter conditions as described above. We then compared the overall productivity and the rate of increase over time (linear regression) for ecology in Argentine, invasion biology in Argentina and invasion biology in Patagonia. Finally, we calculated the number of papers per journal, highlighting those that had Spanish text or abstracts and whether or not they were freely available online (e.g., Scielo database).

\section{Linking what we say with what we do}

To evaluate the relationship between stated priorities and observed research productivity, we built a Chi-square contingency table, using the survey results as the expected frequency (Expected) and the literature analysis as observed frequency (Observed) of research priorities. Analysis was performed with Statistica 7.1 (StatSoft 2005).

\section{Results}

\section{Survey}

Seventy-nine surveys were completed by researchers $(43 \%)$, graduate students $(30 \%)$, undergraduate students (16\%), and managers $(10 \%)$. Among researchers and managers, the majority $(63 \%)$ reported having collaborations with one another. The most common collaborations were in the form of consulting, workshops and joint projects (40-47.5\%), while fewer respondents reported having co-productions, such as joint publications or participating in decision-making and public policies (20-25\%).

Research priorities of students, researchers and managers were not significantly different $(P=0.7)$. Overall, the most important research topics were applied categories, such as

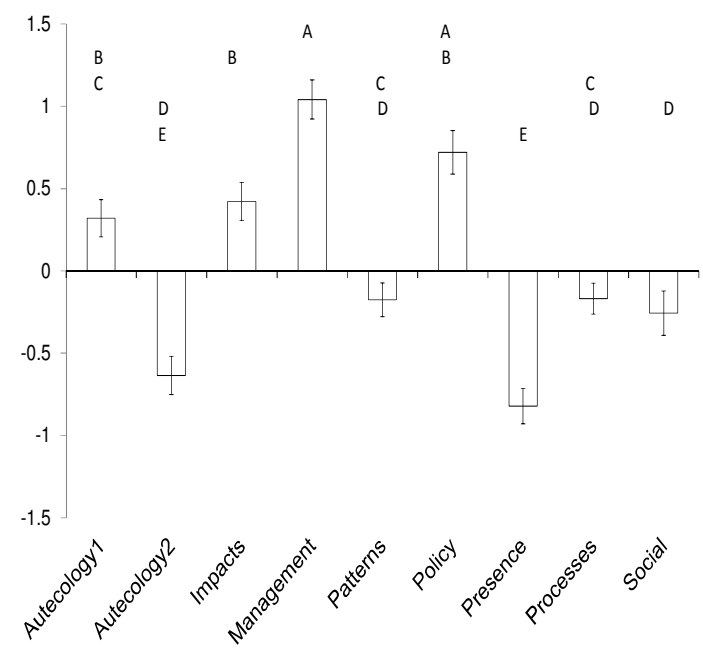

Figure 1. Mean priority values $( \pm \mathrm{SE})$ of research themes as reported by invasion biology practitioners (scale: $2=$ very important; $-2=$ least important). ANOVA results showed no difference between students, researchers and managers, but significant differences were detected between the prioritization of research themes. Themes with different letters were significantly different with a Tukey HSD post hoc tests. See Appendix S1 for survey.

Figura 1. Valores promedio de prioridad $( \pm$ ES) de los temas de investigación según lo informado por profesionales de biología de la invasión (escala: $2=$ muy importante; $-2=$ poco importante). Los resultados del ANOVA muestran que no existen diferencias entre estudiantes, investigadores y gestores, sin embargo se detectaron diferencias significativas en la priorización de los temas de investigación. Temas con diferentes letras fueron significativamente diferentes mediante una prueba post hoc de Tukey HSD.

definition of control methods and development of public policies (Figure 1). Studies of the autecology and impacts of invasive species were the only other two research categories with a positive value in the ranking exercise, while the other specifically ecological topics like determination of presence/absence, patterns and processes were all negative. For its part, the social dimensions of invasive species were also not highly prioritized by survey respondents, but it is of note that this "neutral" result was due to a bi-modal distribution whereby some respondents evaluated this topic very high and others very low.

\section{Academic research products}

Overall, the literature review discovered a total of 559 articles published on invasive species in Argentina; 32\% ( $n=180)$ of these were studies conducted in Patagonia. A sharp increment was registered after 2000, and the number of Argentine papers increased both inside and outside Patagonia during 


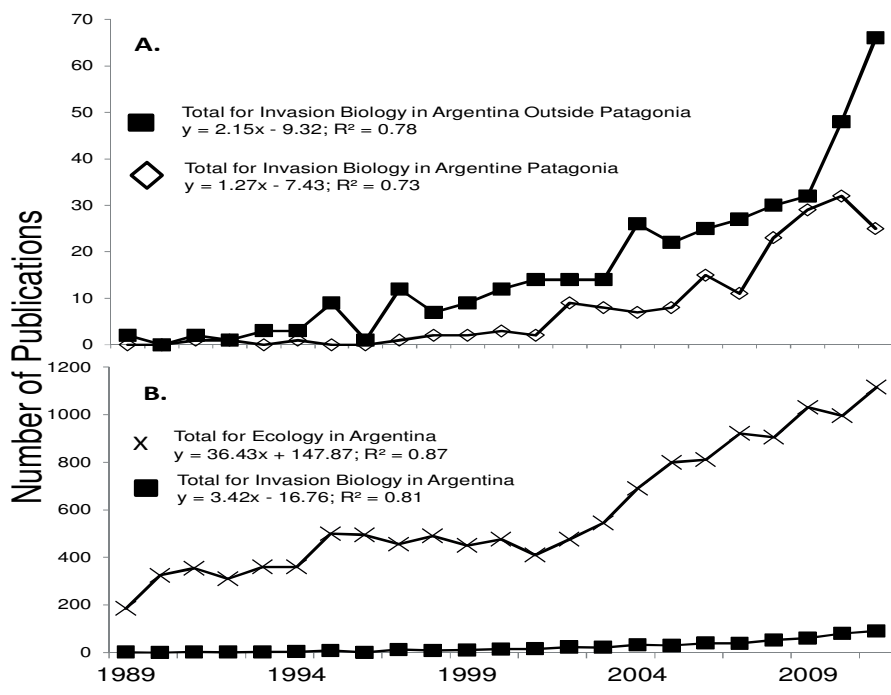

Figure 2. A: Number of invasion biology publications produced in Argentina from 1989-2012 at national and Patagonian regional levels. B: The publication productivity of ecology compared to invasion biology in Argentina.

Figura 2. A. Número de publicaciones sobre invasiones biológicas en Argentina entre 1989 y 2012 a niveles nacional y de la región Patagonia. B: La productividad de la publicaciones en ecología comparada con invasiones biológicas en Argentina. the studied period (Figure 2A). However, the increase in invasive species research was approximately 10 times less than that which was observed for the broader field of Ecology in Argentina (Ecology in Argentina: $\mathrm{y}=36.43 \mathrm{x}+147.87 ; R^{2}=0.87$; Invasion Biology in Argentina: $\mathrm{y}=3.42 \mathrm{x}-16.76 ; R^{2}=0.81$, respectively, Figure 2B).

When publications were organized based on research theme and methodology, there was a dominance of research in the area of invasive species impacts and the use of field sampling methods (Figure 3). On the other hand, research explicitly regarding management was the least commonly addressed study topic, and

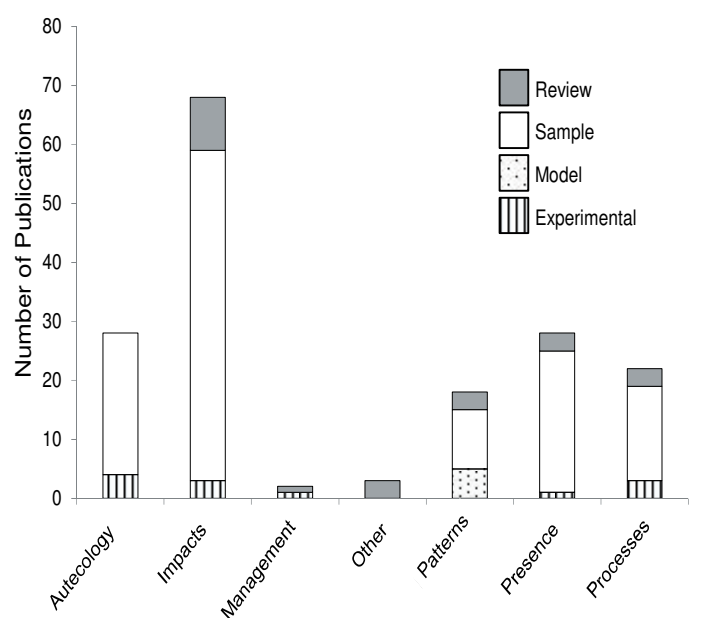

Figure 3. Number of biological invasion publications for Patagonia, categorized by research theme and methodology.

Figura 3. Número de publicaciones sobre invasiones biológicas para Patagonia, categorizadas según tema y metodología de investigación. there was also a lack of experimental studies overall. Ecology-based research themes, such as autecology, presence/absence, patterns and processes, showed similar publication producitivity.

\section{Linking mentalities and actions}

Comparing the frequency of what invasion biology practitioners reported as priorities with the frequency of the academic output, we found significant differences $(P<0.05)$ in various research themes. Specifically, research on invasive species impacts, presence/absence and processes were more frequent in the literature than would be expected from the stated priorities of practitioners, while management and social/policy research was underrepresented in publications based on expectations from surveys (Figure 4 ).

\section{General characterization of invasion biology publications in Patagonia}

A slight majority (51.1\%) of these publications were about animals, while $44 \%$ studied plants and $4.9 \%$ studied both. Furthermore, $86.3 \%$ of the studies in Patagonia addressed the invasion phase, and only a few were concerned with the earlier stages of introduction and establishment, a pattern which was observed for both plant and animal research. Most studies were located in terrestrial habitats $(60.3 \%)$, followed by freshwater $(18.5 \%)$, marine $(12.5 \%)$, freshwater-terrestrial $(6.5 \%)$ and freshwater-marine $(2.2 \%)$ zones. The majority of research was conducted at the community $(71.2 \%)$ or population $(20.1 \%)$ levels, and only a few publications were carried out using ecosystem $(6.0 \%)$ or genetic 


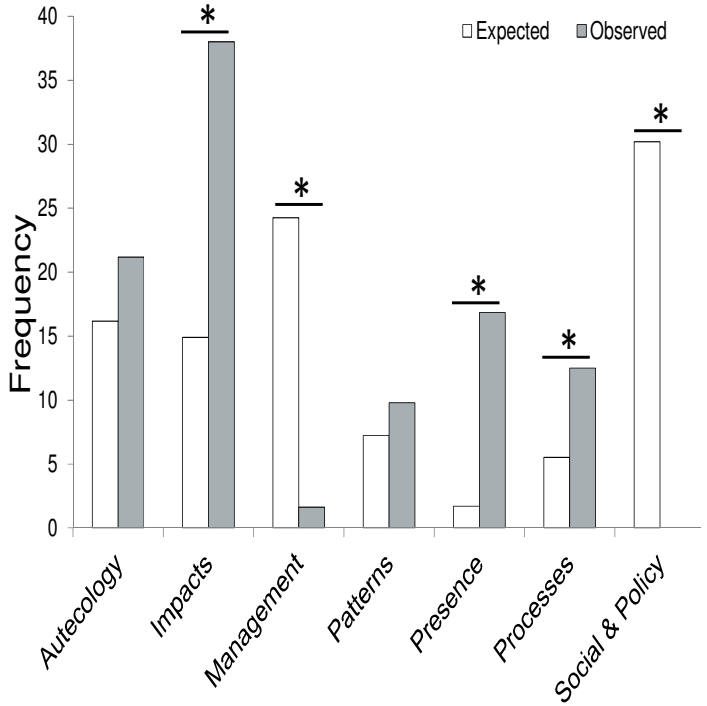

Figure 4. The expected (based on stated priorities in surveys) and observed (based on percentage of publications in the literature review) frequencies of thematic areas in biological invasion research. Significant differences $\left({ }^{*} P<0.05\right)$ were determined with a $\chi^{2}$ contingency table.

Figura 4. Frecuencia esperada (basada en las prioridades definidas en las encuestas) y observada (basada en el porcentaje de las publicaciones en la revisión de literatura) de las áreas temáticas de investigación sobre invasiones biológicas. Se determinaron diferencias significativas $\left({ }^{*} P<0.05\right)$ con una tabla de contingencia $\chi^{2}$.

$(2.7 \%)$ scales. When we examined research into particular species or specific taxonomic groups, only a few had sustained research efforts (Table 1). In particular, salmonids, conifers and deer are relatively well studied as groups, while the algae Undaria pinnatifida and the North American beaver (Castor canadensis) are species with a considerable number of studies in multiple sites and/or over various years.

As anticipated, most academic publications were in English. However, while only 11\% of all the invasion biology articles produced in Argentina had at least an abstract in Spanish, fully $57.1 \%$ of the papers produced in Patagonia were available on the Scielo database, meaning that they are at least have an

Table 1. Number of publications per species and groups of taxonomically similar species.

Tabla1. Número de publicaciones por especie y grupos de especies taxonómicamente similares.

\begin{tabular}{llll}
\hline Species & N & Groups & N \\
\hline Oncorhynchus mykiss & 11 & Trout \& salmon & 31 \\
Undaria pinnatifida & 10 & Conifers & 25 \\
Castor canadensis & 8 & Deer & 11 \\
Cervus elaphus & 7 & Algae & 11 \\
Vespula germanica & 6 & Beaver & 8 \\
Salmo trutta & 5 & Hare \& rabbit & 7 \\
Pinus ponderosa & 5 & Carnivores & 7 \\
Neovison vison & 5 & Pig & 3 \\
Lepus europaeus & 5 & & \\
O. tshawytscha & 4 & & \\
Balanus glandula & 4 & & \\
\hline
\end{tabular}

abstract in Spanish and also are accessible for free. Overall, the 180 articles were published in 100 journals, meaning the vast majority $(82 \%)$ only had one or two papers. Biological Invasions published the most papers $(n=49)$ on invasive species in Argentine Patagonia, followed by Ecología Austral (n= 20) (Figure 5).

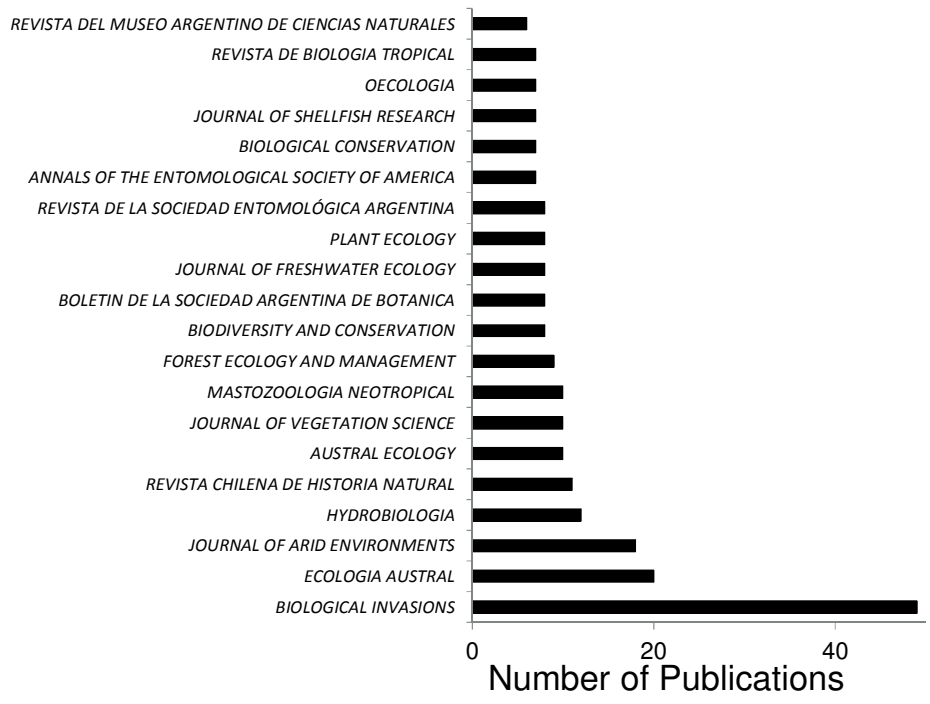

Figure 5. Peer-reviewed academic journals publishing $>5$ papers on invasion biology research in Argentine Patagonia.

Figura 5. Revistas científicas con arbitraje por pares que publicaron $>5$ trabajos en investigación sobre invasiones biológicas en la Patagonia argentina. 


\section{DISCUSSION}

\section{Do what I say, not what I do}

Recent calls within Argentine ecology to enhance the social role of scientists and academic institutions, such as the Argentine Ecology Association and Argentine Mammalogy Society (Donadio 2009), are reinforced by a national political agenda seeking to enhance scientific productivity and quality and link it with social and economic development (Plan Nacional de Ciencia, Tecnología e Inovación, PNCTI 2012-2015). While much of the PNCTI's emphasis is related directly to economic and industrial development, there are also ample space and opportunities to link the ecological sciences with social development and socially relevant research. In this context, our results suggest that invasion biology practitioners in Argentina generally believe that their research agendas should prioritize applied topics, including management and policy. This legitimization of problem-driven questions was valid for both upcoming students and established professionals. In contrast, traditional disciplinary questions were considered of lesser importance. At the same time, it bears mentioning that the responses regarding the social science research theme stood out as the only affirmation that displayed a bi-modal frequency distribution, indicating that there is in this case a value conflict within the professional community regarding the merit of social sciences within invasion biology (i.e., it is either "very high priority" or "very low priority"). This fact is a problem because social research merits further inclusion in invasion biology not only as a basic research question, but because it is has been shown to be a practical necessity in the design and deployment of effective management programs (MacKenzie \& Larson 2010).

Yet, in spite of stated research priorities expressed by the survey participants, our analysis of academic outcomes demonstrated a contrasting scenario. While applied research questions were considered a high priority by invasion biology practitioners, our review showed that those types of studies had the lowest number of publications, which was also re-enforced by the responses from the participants themselves. Surveys also indicated that the type of collaboration between scientists and managers is not "co-production" of information, but rather traditional unidirectional scientific "advising" to the public policy realm. Indeed, we found no publications that explicitly addressed policies or the social dimensions of invasive species. Instead, the research was highly skewed towards studies that looked at the impact of invasive species and used sampling methods, two trends which coincide with Quiroz et al. (2009) in Chile. Research on invasive species impacts could be considered both an applied and basic line of inquiry, depending on the specific project. However, given the general lack of studies that are linked with management or co-produced with managers, it is unclear that these findings are actually being applied or are relevant for practical needs.

There are three potential explanations for this incongruity between what we say and what we do in invasion biology. On the one hand, perhaps it is simply an artifact of the time lag that would be expected to exist when a shift in the values/culture of the scientific community will be reflected in the publication of research findings. It is possible, for example, that the academic papers we reviewed reflect a mentality that was prevalent a decade or more ago. It is reasonable to expect a delay between conceiving an idea and seeing it all the way through to obtaining funds, executing the study and publishing its findings. Therefore, there may not be a true mismatch of values and actions today, but rather a delay in seeing the products of those actions as expressed in the peer-reviewed literature.

Secondly, it is possible that scientists and managers publish their applied findings in technical reports. However, our survey reports indicated that this is not a frequent avenue of collaboration between managers and scientists. Also, these technical reports often remain inaccessible to the broader suite of stakeholders, including managers from different offices, other scientists, decisionmakers and even the general public. At the same time, it bears mentioning that this study specifically sought to determine the academic products of invasion biology and did not address the "grey" literature. However, in a previous work dedicated to how invasive species are studied and managed in Tierra del Fuego (Anderson et al. 2011; Valenzuela et al. 2014), we have found that the role of scientists in informing technical or "grey" literature is common and important in linking information and management. 
Finally, perhaps the most disturbing scenario that requires greater consideration is that these findings indeed reflect a gap between our values and our behavior that is catalyzed and perpetuated by a broken organizational and/or incentive structure in the scientific community. In this case, the academic debate on invasive species could be driven by a hegemonic discourse that occurs in an ethereal realm of ideas dominated by theoretical approaches. This concern is linked to ongoing questioning of whether scientific prestige and professional advancement are too closely linked with publication indices regarding an academic journal's impact factor. It has been argued that to attain these standards, scientists are pressured to publish in English and in journals that require content that fits international priorities, rather than placebased standards of appropriateness (Monjeau et al. 2013). It is also a particularly cautionary note, when we see that in Patagonian invasion biology research a high percentage is actually locally published and / or available in Spanish via the Scielo database. Yet, even so, the research topics continue to not reflect local reality and needs.

The repercussions of these different scenarios have important implications for those who conduct research, as well as the agencies that employ and fund them. Argentina's current scientific evaluation system nominally considers social relevance (Executive Order \#1661/96), stating in Article 20e: "that the evaluation of quality and merit of the scientific and/or technological activity include multiple criteria, which should respect the plurality of the disciplines and areas of knowledge, their impact on universal and national knowledge, and their contribution to the economic and social development of Argentina". However, there is no explanation of how to incorporate or to weigh these multiple criteria. Furthermore, there is no explicit expectation that social relevance is required, nor a clarification of what it would entail. Similar issues are being faced around the world, and the link between academic research and decision-making is certainly not a problem that is unique to the field of invasion biology. However, in Argentine Patagonia, as well as elsewhere, invasion biology is well-positioned to consider the fact that its metaphorical "reflection in the mirror" (i.e., academic publications) does not presently meet society's expectations (e.g., PNCTI 2012-2015) nor even the values its practitioners profess (i.e., survey of research priorities). Considering that researchers in large part define their own organizational structures through the peer-review system, it is fundamentally in our own hands to make sure our priorities and actions align.

\section{The research trends for Patagonian invasion biology compared to other parts of the world}

Overall, the types of research occurring on invasive species in Patagonia are similar to trends observed regionally (Chile: Quiroz et al. 2009) and locally (Tierra del Fuego: Valenzuela et al. 2014). We have experienced a period of explosive increase in productivity that has been focused towards studies that address invasive species impacts. Given the nature of the "invasion" metaphor, it is not a surprise that we have placed a great deal of attention on the "harmful" dimension (i.e., research into impacts) of these introduced species at the expense of the multiple dimensions that the invasion phenomenon entails (Larson 2005). At the same time, though, we can say that a great deal of academic attention has been brought to bear on the subject, and environmental authorities and managers have taken notice (Anderson et al. 2011). Specifically regarding Patagonia, this link has perhaps been facilitated by the high number of publications that are available with at least abstracts in Spanish and/or are accessible through the Scielo online database, but the type of research being conducted still has not fully taken into account the social and applied dimension of invasive species.

At the same time, we would like to offer a caveat in the interpretation of these results. While invasion biology practitioners seem to agree that their research should address social and applied dimensions of this issue, there is still much to do on the basic ecology of introduced and invasive species. Our review found a clear gap in experimental and modeling studies, as well as approaches that seek to determine, in a predictive and explanatory way, the underlying ecological processes and mechanisms that explain the patterns and consequences of invasive species. As put forward by Brown \& Sax (2004), an overemphasis on the negative impacts of invasive species may affect our ability to conduct quality basic ecological research, and does not just limit our concentration on applied questions. Furthermore, this review showed that only a few species, such as 
trout, deer and beavers, have been studied over any significant period of time and with multiple studies or approaches. Such a result is potentially problematic, when we consider that the assemblage of invasive species in southern Patagonia (Valenzuela et al. 2014), Chile (Jaksic 1998) and Argentina (Novillo \& Ojeda 2008) is greater that those whose study allows a critical mass of information to be taken into account regarding their ecology and/or management.

We conclude by arguing that invasion biology has consolidated itself as a major subdiscipline in ecology in Argentine Patagonia. Now, we should more deeply consider the quality and type of the research that is being conducted to position ourselves to use it more fully in the future in theoretical and applied realms. Doing so will help align our ideas, values and actions, while keeping in mind the four founding pillars of the discipline. To date, we have addressed a portion of the goals set out by Huenneke et al. (1988), but to take on this ambitious research agenda we must re-enforce applied studies and also enhance our predictive power with more experimental and modeling approaches. To achieve both of these tasks, it would behoove scientists and managers to conceive of their collaboration not as "advising," but rather as a co-production of information that necessitates a higher degree of integration between the diverse ways of knowing and studying invasive species.

AcKNOWLedgements: This publication is a product of the symposium "Invasions in Patagonia," organized during the $25^{\text {th }}$ Annual Meeting of the Argentine Ecological Association and sponsored by OSARA (www.osara.org). In addition, this research is part of the ECO-Link project, supported by a US NSF Coupled Nature-Human Systems grant (GEO 1262148).

\section{REFERENCES}

Anderson, CB; N Soto; Jl Cabello; PK Wallem; G MARTínEZ PASTUR; ET AL. 2011. Building alliances between research and management to better control and mitigate the impacts of an invasive ecosystem engineer: the pioneering example of the North American beaver in the Fuegian Archipelago of Chile and Argentina. Capítulo 29, pp. 347-359. En: Francis, R (ed.). A Handbook of Global Freshwater Invasive Species. Earthscan Publishing. Londres. Pp. 460.

BROWN, JH \& DF SAX. 2004. An essay on some topics concerning invasive species. Austral Ecol., 29:530-536.

Carpenter, SR; HA MoOney; J Agard; D Capistrano; RS DEFRIES; ET AL. 2009. Science for managing ecosystem services: Beyond the Millennium Ecosystem Assessment. PNAS, 106:1305-1312.

Collins, SL; SR Carpenter; SM SWInTON; DE OREnStein;
DL ChILdERS; ET AL. 2011. An integrated conceptual framework for long-term social-ecological research. Front. Ecol. Environ., 9:351-357.

DAVIS, MA. 2006. Invasion biology 1958-2005: the pursuit of science and conservation. Pp. 35-64. In: Cadotte, MW; SM McMahon \& T Fukami (eds.). Conceptual Ecology and Invasion Biology. Springer. Gran Bretaña.

DAVIS, MA; MK CHew; RJ HobBs; AE Lugo, JJ EwEL; ET AL. 2011. Don't judge species on their origins. Nature, 474:153-154.

DonADIO, E. 2009. Ecólogos y mega-minería, reflexiones sobre por qué y cómo involucrarse en el conflicto minero-ambiental. Ecol. Austral, 19:247-254.

ELton, CS. 1958. The Ecology of Invasions by Animals and Plants. Methuen. Londres.

GURVICH, DE; D RENISON \& F BARRI. 2009. El rol del ecólogo ante la crisis ambiental actual. Ecol. Austral, 9:233-238.

Holbrook, JB \& R Frodeman. 2011. Peer review and the ex ante assessment of societal impacts. Res. Evaluat., 20: 239-246.

Huenneke, L; D Glick; FW WaWeru; RL Brownell JR \& R Goodland. 1988. SCOPE Program on Biological Invasions: a status report. Conserv. Biol., 2:8-10.

JAKSIC, F. 1998. Vertebrate invaders and their ecological impacts in Chile. Biodivers. Conserv., 7:1427-1445.

KuHN, TS. 1962. The Structure of Scientific Revolutions. University of Chicago Press. Pp. 172.

LARSON, BMH. 2005. The war of the roses: demilitarizing invasion biology. Front. Ecol. Environ., 3:495-500.

LOCKWOOD, JL; MF HoOPES \& MP MARCHETTI. 2007. Invasion Ecology. Malden, MA. Blackwell Publishing. Pp. 304.

LubChENCO, J; AM Olson; LB BRUBAKER; SR CARPENTER; MM HOLLAND; ET AL. 1991. The sustainable biosphere initiative: an ecological research agenda. Ecology, 72:371-412.

MackenzIe, BF \& BMH Larson. 2010. Participation under time constraints: Landowner perceptions of rapid response to the emerald ash borer. Soc. Natur. Resour., 23:1013-1022.

McIntosh, RP. 1986. The Background of Ecology: Concept and Theory. Cambridge: Cambridge University Press.

McKeown, B \& D Thomas. 1988. Q Methodology. Newbury Park, CA: Sage Publications.

Millennium Ecosystem Assessment (MEA). 2005. Ecosystems and human well-being. Oct. 92010 http: / /www.maweb.org.

Monjeau, A; J Rau \& CB Anderson. 2013. Regional science: Latin America should ditch Impact Factor. Nature, 499:29.

Novillo, A \& R OJEDA. 2008. The exotic mammals of Argentina. Biol. Invasions, 10:1333-1344.

Núñez, PG; CI Núñez \& CL Morales. 2009. Práctica científica y financiación. Un debate pendiente para la Ecología. Ecol. Austral, 9:239-245.

Pauchard, A; LA Cavieres; R Bustamante; P Becerra \& E RAPPOPORT. 2004. Increasing the understanding of plant invasions in southern South America: First symposium on Alien Plant Invasions in Chile. Biol. Invasions, 6:255-257.

Pauchard, A; CL Quiroz; R García; CB Anderson \& MT KALIN. 2011. Invasiones biológicas en América Latina y El Caribe: Tendencias en investigación para la conservación. Pp. 79-94. In: Simonetti, JA \& R Dirzo (eds.). Conservación Biológica: Perspectivas desde América Latina. Editorial Universitaria, Santiago, Chile. Pp. 193.

PICKetT, STA \& RS OstFeld. 1995. The shifting paradigm in ecology. Pp. 261-278 in: Knight, RL \& SF Bates (eds.). 
A New Century for Natural Resources Management. Island Press, Washington DC.

Plan Nacional de Ciencia, Tecnología e Innovación (PNCTI). 2012-2015. Hacía una Argentina Innovadora: Lineamientos Estratégicos 2012-2013. Pereyra, A (coordinadora). Ministerio de Ciencia, Tecnología e Innovación Productiva Secretaría de Planeamiento y Políticas en Ciencia, Tecnología e Innovación Productiva. Buenos Aires. Pp. 100.

Pysek, P; DM Richardson \& V Jarosík. 2006. Who cites who in the invasion zoo: insights from an analysis of the most highly cited papers in invasion ecology. Preslia, 78:437-468

Quiroz, CL; A Pauchard; LA CAVIERes \& CB ANDERson. 2009. Investigación en invasiones biológicas en Chile: tendencias y desafíos. Rev. Chil. Hist. Nat., 82:497-505.

SimberlofF, D; ET AL. 2011. Non-natives: 141 scientists object. Nature, 475:36.

Speziale, KL; SA Lambertucci; M Carrete \& JL Tella. 2012. Dealing with non-native species: what makes the difference in South America? Biol. Invasions, 14: 1609-1621.

STAT SOFT INC. 2011. STATISTICA, version 7.1.

ValenZuela, AEJ; CB Anderson; L Fasola \& JL Cabello. 2014. Linking invasive exotic species and their ecosystem impacts in Tierra del Fuego to test theory and determine action. Acta Oecol., 54: 110-118

Williams, M. 1996. Biological Invasions. London. Chapman and Hall. 


\section{SUPPLEMENTARY INFORMATION}

\section{Appendix 1. SurveY.}

\section{Encuesta: Invasiones en Argentina}

La presente encuesta se desprende del Simposio titulado "Invasiones en la Patagonia: ¿De dónde vienen y hacia dónde van las especies exóticas en la región más extensa de la Argentina?", que fuera realizado durante la última Reunión Argentina de Ecología. Los resultados de la misma serán presentados en la Sección Especial de la revista Ecología Austral que se desprenderá a partir de dicho simposio.

Edad (años)*

- 20-29

- 30-39

- 40-49

- 50-59

- $>60$

¿Usted es...?*

- Estudiante de grado

- Estudiante de postgrado

- Investigador

- Gestor

- Otro

Si se identifica como investigador, ¿tiene una activa colaboración con gestores? ${ }^{*}$ (vale la viceversa si usted se identifica como gestor)

\section{- Sí}

- No

En caso que haya respondido que SI a la pregunta anterior, ¿cómo lo hace? (indique todas las opciones que correspondan)

- Postula/desarrolla proyectos en conjunto

- Publicaciones en conjunto

- Talleres

- Asesorías
- Diseño de políticas públicas

- Participación en instancias de toma de decisiones

- Otro

¿Cuál es su área de trabajo?

Priorice las afirmaciones de acuerdo a su relevancia para la investigación sobre especies invasoras

* Required

De las siguientes afirmaciones debe elegir una como "muy importante", dos como "importantes", tres como "neutras", dos como "poco importantes" y una como "sin importancia". Las afirmaciones NO se pueden repetir es decir que no pueden ser "muy importante" y "neutra" al mismo tiempo.

- Manejo: Definir métodos eficaces para prevenir, detectar, controlar, mitigar y/o erradicar las especies invasoras

- Social: Determinar percepciones sociales y valores asociados a las especies invasoras

- Autoecología1: Estudiar la biología y ecología de las especies invasoras

- Autoecología2: Caracterizar los ecosistemas invadidos

- Presencia: Registrar la presencia/ausencia de todas las especies invasoras en un área determinada

- Patrones: Investigar distribuciones y tasas de expansión de las especies invasoras

- Impacto: Cuantificar los impactos ecológicos, culturales y económicos de las especies invasoras

- Políticas: Desarrollar políticas públicas sobre especies invasoras

- Procesos: Analizar las vías de transporte y dispersión de las especies invasoras 